Our Nature (2006)4:10-19

\title{
Taxonomic Studies on Some Freshwater Diatoms from the Eastern Terai Region, Nepal
}

\author{
S.K. Rai \\ Department of Botany, Post Graduate Campus, Tribhuvan University, Biratnagar, Nepal \\ E-mail: shivarai2003@yahoo.com
}

Received: 20.07.2006; Accepted: 5.10.2006

\begin{abstract}
The present paper describes the morphology and distribution of 17 freshwater diatom species (Bacillariophyceae) collected from rivers, ponds, ditches and wetlands of the eastern Terai region, Nepal. They belong to the genera Cyclotella (1), Ceratoneis (1), Fragilaria (1), Eunotia (1), Navicula (3), Pinnularia (1), Gyrosigma (1), Gomphonema (2), Cymbella (3), Epithemia (1), and Hantzschia (2). Cyclotella meneghiniana Kuetz., Ceratoneis arcus (Ehr.) Kuetz., Fragilaria capucina Desmaz. var. mesolepta Rabenh., Eunotia lunaris (Ehr.) Grun., Navicula perrotettii Grun., Gomphonema lanceolatum fo. turris (Ehr. c.p.) Hust., and Cymbella tumida (Bréb.) Van. Heurck have previously been reported from the eastern Terai region but Navicula radiosa Kuetz., Gyrosigma kuetzingii (Grun.) Cl., Gomphonema sphaerophorum Ehr., Cymbella aspera (Ehr.) Cl, and Hantzschia amphioxys (Ehr.) Grun. var. capitata Muell. are new records for this area. Navicula gastrum Ehr., Pinnularia viridis (Nitzs.) Ehr. var. intermedia $\mathrm{Cl} .$, Cymbella reinhardtii Grun., Hust., Epithemia sorex Kuetz. and Hantzschia virgata (Roper) Grun. are new records for Nepal.
\end{abstract}

Key words: Algae, Bacillariophyceae, freshwater diatoms, Terai, Nepal

\section{Introduction}

Diatoms are unicellular, sometimes colony forming eukaryotic microscopic algae, which live free floating or attached to surfaces in fresh-waters and in the oceans, or live in moist soils. Their glasslike cell wall is composed of pectic compounds usually impregnated with silica and has two overlapping halves the epivalve and the hypovalve. Diatomaceous earth accumulated in some geologic formations is mined and used for a number of industrial applications for example in filters.

The eastern Terai region of Nepal is part of the northern Indo-Gangetic plains and is located between $26^{\circ} 20^{\prime}$ to $26^{\circ} 55^{\prime} \mathrm{N}$ latitude and $86^{\circ} 08^{\prime}$ to $88^{\circ} 12^{\prime} \mathrm{E}$ longitude. It extends c. $192 \mathrm{~km}$ east-west and 16 to $40 \mathrm{~km}$ northsouth between the Siwalik Hills and the border of India, occupying an area of about
$7217 \mathrm{~km}^{2}$. Its elevation ranges from 70 to 300 $\mathrm{m}$ amsl. It comprises the Jhapa, Morang, Sunsari, Saptari, Siraha and the southern part of the Udayapur district. The major rivers in the region are the Sapta Koshi, Mechi, Kankai, Triyuga, and Kamala which originate in the Himalayas and flow to the south. Other seasonal rivers originating in the Mahabharat and Siwalik Hills have often very low water levels during the dry season. The region has a subtropical monsoon climate with hot and wet summers and mild and dry winters. The mean temperature, annual rainfall and relative humidity are $25^{\circ} \mathrm{C}, 2169.5 \mathrm{~mm}$, and $74 \%$, respectively.

The first investigations on diatoms in Nepal were made by Carter (1926), followed by Hirano $(1955,1963,1969,1984)$, Suxena and Venkateswarlu (1968), Suxena et al. 


\section{S. K. Rai / Our Nature (2006)4:10-19}

(1972), Hickel (1973a, b), Ishida (1986), Aryal and Lacoul (1996), Juettner et al. (1996), Rothfritz et al. (1997), Juettner et al. (2000), Cantonati et al. (2001), Juettner et al. (2003), Juettner et al. (2004), and Simkhada and Juettner (2006). So far 263 diatom taxa have been reported from Nepal (Baral, 1999). Most of these reports were from the high Himalaya and the mountain regions of the Middle Hills. Although the abundance of lotic and lentic habitats provide diverse habitats for algae in the Terai region, this area of the country remains poorly investigated. Only recently some studies have investigated diatoms from Biratnagar (Rai and Rai, 2005), Maipokhari lake, Ilam (Rai, 2005), and the Koshi Tappu area (Simkhada et al., 2006).

\section{Materials and methods}

Between 2002-2004, thirteen samples were collected from ten localities and fixed with $4 \%$ formalin. The samples were deposited in the laboratory of the Botany Department, P.G. Campus, Biratnagar. Permanent slides were prepared following the method by Patrick and Reimer (1966) and photo micrographs were taken using a Nikon E400 with H-III photographic attachment. Taxonomic identifications were made by consulting various literatures and monographs and the nomenclature followed Hendey (1964).

The abbreviations used in the text are: $\mathrm{L}=$ cell length, $\mathrm{W}=$ cell width, $\mathrm{Str}=$ striae, $\mathrm{P}=$ page number, $\mathrm{Tab}=$ table number, $\mathrm{Pl}=$ plate number, Fig $=$ figure number, $\mathrm{CN}=$ collection number, $\mathrm{Lc}=$ locality, $\mathrm{D}=$ date of collection and Alt $=$ altitude.

\section{Algal Localities}

Diatoms have been collected from the following localities (Map 1).
1. Satasi River, Dudhe, Jhapa: edge of shallow running water (Alt. $128 \mathrm{~m}$ ).

2. Sukrabare, Kechana, Morang: water cannel near Kamal Pokhari (Alt. 73 m).

3. Pathari, Morang: slow running water near Mahendra Rajmarg (Alt. 140 m).

4. Biratnagar, Morang: pond at Birendra Sabha Griha (Alt. 72 m).

5. Biratnagar, Morang: ditches on both sides of Pitchhra Nahar (Alt. $72 \mathrm{~m}$ ).

6. Tarahara, Sunsari: road side ditches in front of Agriculture Research Centre (Alt. $155 \mathrm{~m}$ ).

7. Koshi Tappu, Sunsari: wetlands in Koshi Tappu Wildlife Reserve (Alt. 206 $\mathrm{m})$.

8. Sapta Koshi River, Sunsari: plankton from the river littoral in the Koshi Tappu Wildlife Reserve (Alt. 206 m).

9. Koshi Barrage, Sunsari: water damp or reservoir west of Bhantabari (Alt.162 m)

10. Triyuga River, Udayapur: slow running water near Gaighat (Alt. $152 \mathrm{~m}$ ).

\section{Observations}

Class: Bacillariophyceae

Order: Bacillariales

Sub-order: Coscinodiscineae

Family: Coscinodiscaceae

Genus: Cyclotella Kuetzing 1834

1. Cyclotella meneghiniana Kuetz. (Fig. 2)

Smith, G.M. 1950, P. 462, Fig. 371; Tiffany, L.H. and M.E. Britton 1952, P. 218, P1. 58, Fig. 660; Prasad, B.N. and M.N. Srivastava 1992, P. 160, Pl. 24, Figs. 1-2

Valves circular; central area smooth or rarely finely punctuate; marginal striae coarse, wedge-shaped.

Diameter $13.5 \mu \mathrm{m}$, Str 9 in $10 \mu \mathrm{m}, \mathrm{CN} 75$, Lc 4 and 5, D 12-01-2003. 


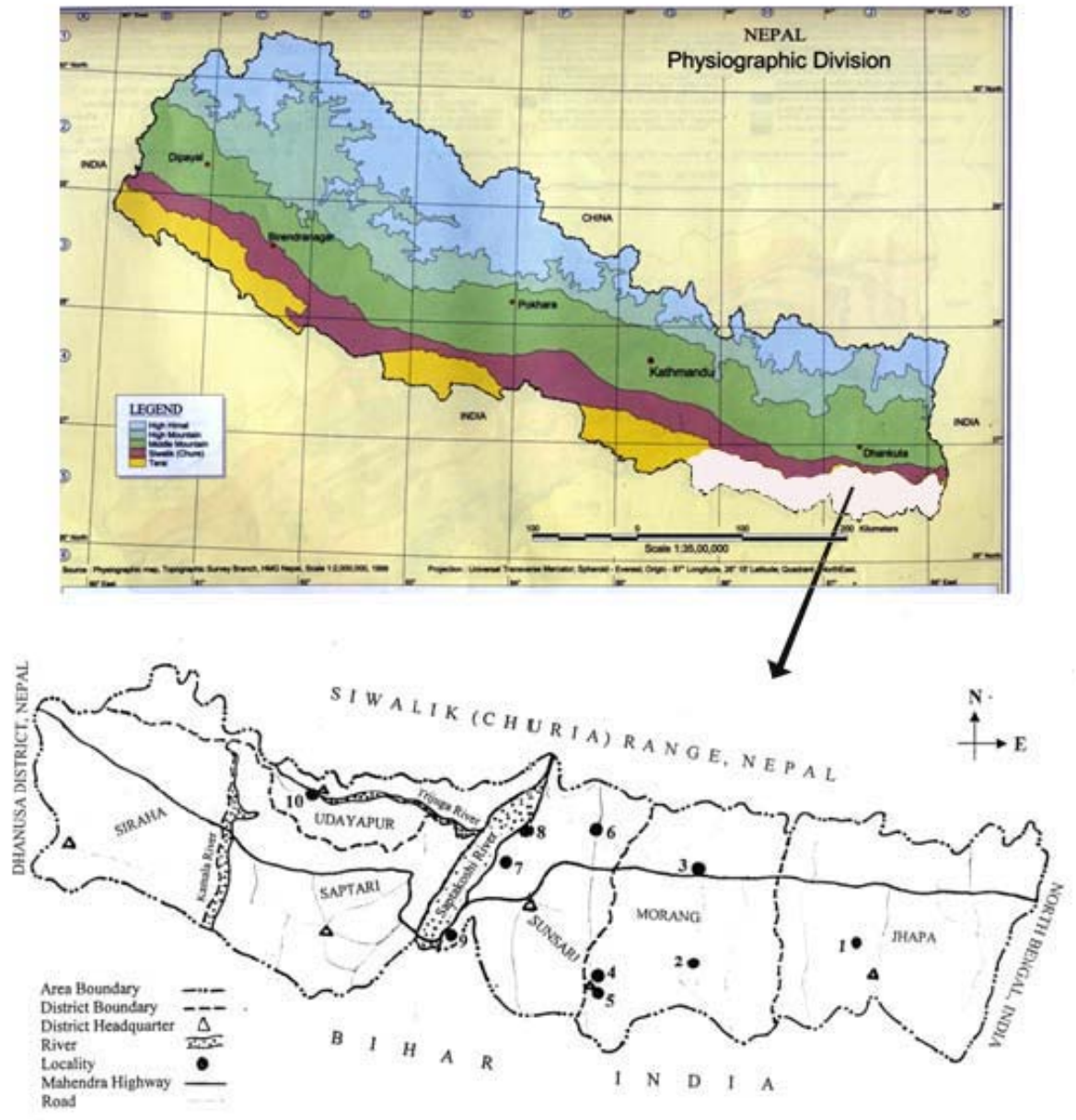

Map 1. Eastern Terai region of Nepal 
S. K. Rai / Our Nature (2006)4:10-19
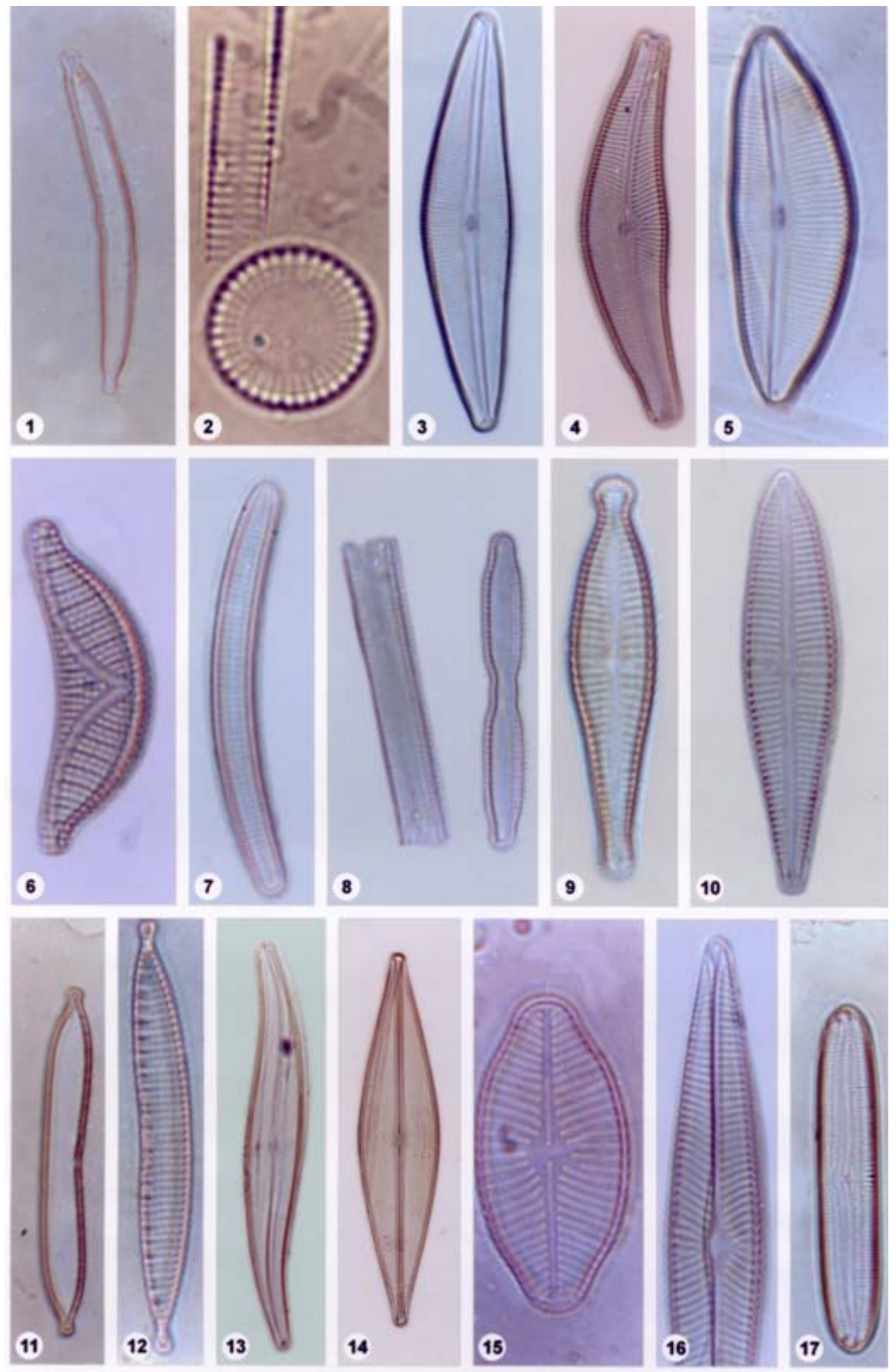


\section{S. K. Rai / Our Nature (2006)4:10-19}

Fig. 1. Ceratoneis arcus (Ehr.) Kuetz. $\times$ 900; Fig. 2. Cyclotella meneghiniana Kuetz. $\times 1400$; Fig. 3.Cymbella aspera (Ehr.) Cl. $\times$ 1100; Fig. 4.Cymbella tumida (Breb.) Van. Heurck. $\times$ 930; Fig. 5.Cymbella reinhardtii Grun., Hust. $\times$ 900; Fig. 6. Epithemia sorex Kuetz. $\times 2200$; Fig. 7. Eunotia lunaris (Ehr.) Grun. $\times 2250$; Fig. 8. Fragilaria capucina Desmaz. var. mesolepta Rebenh. ×2235; Fig. 9.Gomphonema sphaerophorum Ehr. ×2250; Fig. 10. Gomphonema lanceolatum fo. turris (Ehr. c.p.) Hust. $\times 2265$; Fig. 11. Hantzschia amphioxys (Ehr.) Grun. var. capitata Muell. $\times$ 900; Fig. 12. Hantzschia virgata (Roper) Grun. $\times 2265$; mFig. 13. Gyrosigma kuetzingii (Grun.) Cl. $\times 920$; Fig. 14. Navicula perrotettii Grun. $\times$ 450; Fig. 15. Navicula gastrum Ehr. $\times 2245$; Fig. 16. Navicula radiosa Kuetz. $\times 2250$; Fig. 17. Pinnularia viridis (Nitzs.) Ehr. var. intermedia $\mathrm{Cl} . \times 930$.

Distribution in Nepal: pond at Dillibazar, 1300 m, Kathmandu (Hirano, 1963); Birendra Sabha Griha pond, $72 \mathrm{~m}$, Biratnagar (Rai and Rai, 2005; Misra et al.).

Sub-order: Fragilarineae

Family: Fragilariaceae

Genus: Ceratoneis Ehrenberg 1840

2. Ceratoneis arcus (Ehr.) Kuetz. (Fig. 1) Smith, G.M. 1950, P. 483, Fig. 391; Hustedt, F. 1959, P. 179, Fig. 684 b

Valves arcuate with a prominent tumescence in the middle of the concave side; apices rostrate-capitate; axial area narrow and towards the concave margin

L 57-60 $\mu \mathrm{m}$, W 5-6.5 $\mu \mathrm{m}$, Str 14-17 in $10 \mu \mathrm{m}$, CN 35, Lc 8 and 9, D 14-05-2002.

Distribution in Nepal: stream below Namche Bazar, 2900-4200 m, Solukhumbu (Suxena and Venkateswarlu, 1968); a stream at Kungbachen, 4150 m (Hirano, 1984); Sapta Koshi river, 206 m, Koshi Tappu, Sunsari; Rawa Khola, 720 m, Manglabare, Khotang; Gokyu lake III, 4770 m, Solukhumbu (Misra et al.)

Genus: Fragilaria Lyngbye 1819

3. Fragilaria capucina Desmaz. var. mesolepta Rabenh. (Fig. 8)

Tiffany, L.H. and M.E. Britton 1952, P. 234, Pl. 62, Fig. 699; Hustedt, F. 1959, P. 144, Figs. $659 \mathrm{~h}-\mathrm{i}$
Cells forming long chains; valves linear with pseudoraphe and more or less constricted at the centre of the valve; central area rectangular to elliptical; parallel fine striae.

L 33-35 $\mu \mathrm{m}$, W 2-4 $\mu \mathrm{m}$, Str $14-16$ in $10 \mu \mathrm{m}$, CN 112, Lc 8 and 9, D 19-04-2003.

Remark: specimens found have slightly swollen constricted area at the valve centre.

Distribution in Nepal: Koshi Barrage reservoir, $162 \mathrm{~m}$, Sunsari (Misra et al.).

Sub-order: Eunotiineae

Family: Eunotiaceae

Genus: Eunotia Ehrenberg 1837

4. Eunotia lunaris (Ehr.) Grun. (Fig. 7)

Tiffany, L.H. and M.E. Britton 1952, P. 238, Pl. 64, Fig. 730; Hustedt, F. 1959, P. 302, Fig. 769a; Prasad, B.N. and M.N. Srivastava 1992, P. 181, Pl. 25, Fig. 3

Valves crescentric to arcuate, more or less parallel sides and slightly narrower rounded apices; short raphe at the ventral margin near the poles; polar nodules small; striae parallel

L 45-46 $\mu \mathrm{m}$, W 4-5 $\mu \mathrm{m}$, Str 14-15 in $10 \mu \mathrm{m}$, CN 129, Lc 3 and 6, D 12-03-2004.

Distribution in Nepal: Bhote Koshi river, $5050 \mathrm{~m}$, Solukhumbu (Suxena and Venkateswarlu, 1968); roadside ditches at Tarahara, $155 \mathrm{~m}$, Sunsari (Misra et al.).

Sub-order: Naviculineae

Family: Naviculaceae 
S. K. Rai / Our Nature (2006)4:10-19

Genus: Navicula Bory 1822, emend. Cleve 1894

5. Navicula gastrum Ehr. (Fig. 15)

Tiffany, L.H. and M.E. Britton 1952, P. 256, Pl. 67, Fig. 786; Hustedt, F. 1961-1966, P. 799, Fig. 1771; Cholnoky, B.J. 1966, P. 34, Tab. 4, Fig. 88

Valves broadly elliptic; apices short rostrate and broadly rounded; axial area narrow, parallel; central area widened and irregular; raphe straight, median with distinct central nodules; striae radiate throught, striae around the central area alternately long and short.

L $33 \mu \mathrm{m}, \mathrm{W} 15.5 \mu \mathrm{m}$, Str 8-11 in $10 \mu \mathrm{m}, \mathrm{CN}$ 227, Lc 10, D 10-12-2003.

Distribution in Nepal: new record for Nepal.

6. Navicula perrotettii Grun. (Fig. 14)

Hustedt, F. 1961-1966, P. 56, Fig. 1205a; Foged, N. 1980, P. 652, Pl. 8, Figs. 1-2

Valves broadly lanceolate; apices rostrate capitate or slightly rounded; axial area narrow parallel; central area moderately wide and longitudinally elongated; raphe straight with distinct central nodules; striae parallel and convergent towards the poles; areolae rectangular and perpendicular to the raphe creating longitudinal striae parallel to axial area.

L $195 \mu \mathrm{m}$, W $42-44 \mu \mathrm{m}$, transverse Str 13 in $10 \mu \mathrm{m}$, longitudinal Str 9-10 in $10 \mu \mathrm{m}, \mathrm{CN}$ 201, Lc 10, D 25-05-2003.

Distribution in Nepal: roadside ditches in front of Sent Joseph's School, $72 \mathrm{~m}$, Biratnagar (Rai and Rai, 2005).

7. Navicula radiosa Kuetz. (Fig. 16)

Tiffany, L.H. and M.E. Britton 1952, P. 255, Pl. 67, Fig. 780; Foged, N. 1983, P. 446, Pl.
3, Fig. 18; Prasad, B.N. and M.N. Srivastava 1992, P. 212, Pl. 28, Fig. 4

Valves lanceolate; apices rounded and slightly rostrate or cuneate; axial area narrow, parallel, widening into a rhombic central area; raphe straight with central nodules deflected to one side; striae radiate and convergent towards the poles.

L $72 \mu \mathrm{m}, \mathrm{W} 10 \mu \mathrm{m}$, Str $10-12$ in $10 \mu \mathrm{m}, \mathrm{CN}$ 92, Lc 7, D 21-12-2002.

Distribution in Nepal: Luitel Bhanjyang, 770 m, Gorkha; Kali Gandaki, 2600 m, Mustang; Tukucha Moor, $2640 \mathrm{~m}$, Mustang; Manang Bhot Base Camp, 3500 m, Manang (Hirano, 1963); Phewa Lake, 967 m, Kaski (Nakanishi, 1986); new record for the eastern Terai.

\section{Genus: Pinnularia Ehrenberg 1840}

8. Pinnularia viridis (Nitzs.) Ehr. var. intermedia $\mathrm{Cl}$. (Fig. 17)

Foged, N. 1982, P. 356, Pl. 8, Fig. 3

Valves linear or elliptic-linear with parallel or slightly convex sides; apices slightly pointed or broadly rounded; axial area wide, linear, c. $1 / 4$ of the valve width; large central area somewhat elliptic and slightly wider on one side; raphe broad and undulate with approximated central nodules and hooked terminal fissures; striae very coarse, punctuate, striae radiate becoming parallel convergent towards the poles.

L 92-93 $\mu \mathrm{m}$, W 15-16 $\mu \mathrm{m}$, Str 9-10 in $10 \mu \mathrm{m}$, CN 86, Lc 7, D 21-12-2002.

Distribution in Nepal: new record for Nepal.

Genus: Gyrosigma Hassall 1845, emend. Cleve 1894

9. Gyrosigma kuetzingii (Grun.) Cl. (Fig.13) 


\section{S. K. Rai / Our Nature (2006)4:10-19}

Hustedt, F. 1938, P. 410, Tab. 14, Fig. 2; Tiffany, L.H. and M.E. Britton 1952, P. 269, Pl. 66, Fig. 761

Valves sigmoid, lanceolate, tapering to narrowly rounded apices; axial area narrow, linear; small elongated elliptical central area; raphe thin, sigmoid, slightly excentric towards poles with distinct polar nodules; areolae rectangular and perpendicular to the raphe creating a transverse and longitudinal striation

L $100 \mu \mathrm{m}$, W $13 \mu \mathrm{m}$, transverse Str 21 in 10 $\mu \mathrm{m}$, longitudinal Str 25 in $10 \mu \mathrm{m}, \mathrm{CN} 208$, Lc 2, D 07-06-2003.

Distribution in Nepal: pond at Luitel Bhanjyang, 770 m, Gorkha (Hirano, 1955); new record for the eastern Terai.

Family: Gomphonemaceae

Genus: Gomphonema C.A. Agardh 1824

9. Gomphonema lanceolatum fo. turris (Ehr. c.p.) Hust. (Fig. 10)

Gandhi, H.P. 1959, P. 325, Fig. 47; Hadi, R.A.M. et al. 1984, P. 535, Pl. 5, Fig. 78; Pl. 12, Fig. 205

Valves broad, clavate with an apiculate head pole and a capitate foot pole; axial area linear, widening into a round or elliptical central area, which is wider on one side and has an isolated pore on the primary side of the central nodule; raphe straight with hooked terminal fissures; striae coarsely punctate, slightly radiate, striae shortend and wider around the central area.

L $50 \mu \mathrm{m}, \mathrm{W} 10.5 \mu \mathrm{m}, \mathrm{Str} 11-12$ in $10 \mu \mathrm{m}, \mathrm{CN}$ 200, Lc 10, D 25-05-2003.

Distribution in Nepal: ponds in Koshi Tappu, 206 m, Sunsari (Simkhada et al., 2006).
10. Gomphonema sphaerophorum Ehr. (Fig.9)

Tiffany, L.H. and M.E. Britton 1952, P. 272, P1. 72, Fig. 847; Prasad, B.N. and M.N. Srivastava 1992, P. 257, Pl. 33, Fig. 10

Valves broad, clavate with capitate head pole and slightly capitate foot pole; axial area linear, narrow, and widening into a small circular central area with an isolated pore on the primary side of the central nodule; raphe straight with distinct central nodules; striae punctate and slightly radiate, wider at the centre of the valve

L $44 \mu \mathrm{m}$, W $9 \mu \mathrm{m}$, Str $11-12$ in $10 \mu \mathrm{m}, \mathrm{CN}$ 202, Lc 10, D 25-05-2003.

Distribution in Nepal: pond near Phewa Lake, 967 m, Pokhara (Hirano, 1955); pond near police station, Mahendranagar, Kanchanpur (Habib, 1997); new record for the eastern Terai.

Genus: Cymbella C.A. Agardh 1830

11. Cymbella aspera (Ehr.) Cl. (Fig. 3)

Tiffany, L.H. and M.E. Britton 1952, P. 279, P1. 73, Fig. 858; Hadi, R.A.M. et al. 1984, P. 534, P1. 5, Fig. 74; P1. 11, Fig. 195

Valves asymmetric, semi-lanceolate, dorsal side convex and ventral side almost straight and slightly expanded at the centre of the valve; apices slightly rostrate and broadly rounded; axial area broad and widening into an elliptic central area; raphe located slightly closer to the ventral valve margin, very slightly curved; striae radiate.

L $136 \mu \mathrm{m}$, W $30 \mu \mathrm{m}$, Str 7-10 in $10 \mu \mathrm{m}, \mathrm{CN}$ 196, Lc 10, D 25-05-2003.

Remarks: present specimen differs as it has slight constriction below the truncately 


\section{S. K. Rai / Our Nature (2006)4:10-19}

rounded poles and radiate transverse striation.

Distribution in Nepal: pond at Thaple Himal, $4000 \mathrm{~m}$, Manang (Hirano, 1955); new record for the eastern Terai.

12. Cymbella reinhardtii Grun.,Hust. (Fig. 5) Hustedt, F. 1938, P. 424, Tab. 24, Figs. 27-28

Valves only slightly semilanceolate almost lanceolate, dorsal and ventral sides convex; apices very slightly rostrate and rounded; axial area narrow widening into a small rhombic central area; raphe slightly undulate; striae radiate

L $80 \mu \mathrm{m}$, W $26 \mu \mathrm{m}$, Str 8-9 (dorsal) and 10 (ventral) in $10 \mu \mathrm{m}, \mathrm{CN} 196$, Lc 10, D 25-052003.

Distribution in Nepal: new record for Nepal.

13. Cymbella tumida (Bréb.) Van. Heurck. (Fig. 4)

Tiffany, L.H. and M.E. Britton 1952, P. 278, Pl. 74, Fig. 860; Gandhi, H.P. 1999, P. 20, Pl. 1, Figs. 24-26; P. 91, Pl. 1, Figs. 19-20

Valves semilanceolate with a convex dorsal margin and almost straight or slightly convex ventral margin with a slight expansion in the centre of the valve; apices rostrate and broadly rounded; axial area narrow, widening into a large round central area with a single pole on the ventral side; raphe slightly curved, with distinct central nodules located slightly closer to the ventral valve margin; striae coarse, punctuate and radiate.

L $97 \mu \mathrm{m}$, W $20.5 \mu \mathrm{m}$, Str 9-10 in $10 \mu \mathrm{m}, \mathrm{CN}$ 76, Lc 5, D 25-03-2003.

Distribution in Nepal: pond at Arughat Bazar, 710 m, Gorkha (Hirano, 1955; 1984); roadside ditches, Mahendranagar (Habib, 1997); Pitchhra pond, 72 m, Biratnagar (Rai and Rai, 2005).
Family: Epithemiaceae

Genus: Epithemia Brébisson 1838

14. Epithemia sorex Kuetz. (Fig. 6)

Tiffany, L.H. and M.E. Britton 1952, P. 281, Pl. 75, Fig. 881; Foged, N. 1983, P. 441, Pl. 6, Fig. 7; Hadi, R.A.M. et al. 1984, P. 536, Pl. 5, Fig. 83; P1. 12, Figs. 213-214.

Valves crescentic with convex dorsal margin and concave ventral margin; apices capitate and broadly rounded; raphe biarcuate, bending towards the dorsal edge at the centre; costae distinct and radiate with two to three alveoli between the costae

L $35 \mu \mathrm{m}$, W $9.5 \mu \mathrm{m}$, Costae 5-6 in $10 \mu \mathrm{m}$, Str 13 in $10 \mu \mathrm{m}, \mathrm{CN} 128$, Lc 9, D 28-03-2003.

Distribution in Nepal: new record for Nepal.

Family: Bacillariaceae

Genus: Hantzschia Grunow 1880

15. Hantzschia amphioxys (Ehr.) Grun. var. capitata Muell. (Fig. 11)

Tiffany, L.H. and M.E. Britton 1952, P. 289, Pl. 75, Fig. 887; Prasad, B.N. and M.N. Srivastava 1992, P. 313, Pl. 31, Fig. 6

Valves slightly reniform, convex dorsal valve margin, raphe located at concave ventral margin; apices subcapitate and rounded; fibulae distinct wider spaced at the centre of the valve; striae parallel, slightly radiate towards the apices.

L $67 \mu \mathrm{m}, \mathrm{W} 7-8 \mu \mathrm{m}$, keel punctae $7-8$ in 10 $\mu \mathrm{m}, \mathrm{CN} 217$, Lc 3, D 07-06-203

Distribution in Nepal: Maipokhari lake, 2150 m, Ilam (Rai, 2005); new for the eastern Terai.

16. Hantzschia virgata (Roper) Grun. (Fig. 12) 


\section{S. K. Rai / Our Nature (2006)4:10-19}

Sinnu, N.A. and L.E. Squires 1985, P. 314 , Pl. 18, Fig. 163

Valves reniform, convex dorsal valve margin, raphe located at concave ventral margin; apices capitate and rounded; fibulae distinct wider spaced at the centre of the valve; striae parallel, slightly radiate towards the apices.

L $49 \mu \mathrm{m}, \mathrm{W}$ 5.5-6 $\mu \mathrm{m}$, keel punctae 7 in 10 $\mu \mathrm{m}$, Str 13 in $10 \mu \mathrm{m}, \mathrm{CN} 227, \mathrm{Lc}$ 1, D 10-122003.

Distribution in Nepal: new record for Nepal.

\section{Conclusion}

In the present study 17 diatom species belonging to 11 genera were recorded from a variety of freshwater habitats in the eastern Terai of Nepal. Navicula radiosa, Gyrosigma kuetzingii, Gomphonema sphaerophorum, Cymbella aspera, and Hantzschia amphioxys were first records for this area. Navicula gastrum, Pinnularia viridis var. intermedia, Cymbella reinhardtii, Epithemia sorex, and Hantzschia virgata were new records for the diatom flora of Nepal.

Taxonomic investigations on the diatom flora of Nepal are still very limited and most studies were performed in mountainous areas. The Terai plain with its hot and humid climate as well as rich lotic and lentic aquatic habitats requires a more extensive exploration and documentation of its algal flora. The establishment of a diatom database would be an essential contribution to the conservation of Nepal's aquatic biodiversity.

\section{Acknowledgements}

I would like to thank Dr. M.N. Srivastava, Scientist, Central Drug Research Institute (CDRI), Lucknow for providing the photomicrography facilities and identification of the specimens. I also thank the Director, National Botanical Research Institute (NBRI),
Lucknow for providing the library facilities. I am very thankful to the UGC, Nepal for the financial assistance.

\section{References}

Aryal, S. and P. Lacoul 1996. Water quality and diversity of diatoms in Punyamati river, Nepal. Ecoprint 3(1): 45-49.

Baral, S.R. 1999. Algae of Nepal. In Nepal Nature's Paradise (Eds. T.C. Majupuria and R. Kumar), Gwalior, India. pp. 655-681.

Cantonati, M., G. Corradini, I. Juettner and E.J. Cox 2001. Diatom assemblages in high mountain streams of the Alps and the Himalaya. Nova Hedwigia, Beiheft 123: 37-61.

Carter, N. 1926. Fresh water algae from India. Records bot. Surv. India 9(4): 263-302.

Cholnoky, B.J. 1966. Die diatomeen im unter laufe des Okawango-Flusses. Nova Hedwigia 21: 1-122.

Foged, N. 1980. Diatoms in Egypt. Nova Hedwigia 33(1-4): 629-675-707.

Foged, N. 1982. Diatoms in Human Tissue. Nova Hedwigia 36(2-4): 345-379.

Foged, N. 1983. Diatoms in fountains, reservoirs and some other humid and dry localities in Rome, Italy. Nova Hedwigia 38: 433-468

Gandhi, H.P. 1959. Fresh water diatoms from Sagar in the Mysore State. J. Ind. bot. Soc. 38(3): 305-331.

Gandhi, H.P. 1999. Fresh water diatom of Cental Gujrat. B. Singh and M.P. Singh, Deharadun, India. $324 \mathrm{p}$.

Habib, I. 1997. Algal flora from Mahendranagar, Nepal. J.Econ. and Taxon. Bot. (India) 21(1): 19-26.

Hadi, R.A.M., A.A. Al-saboonchi and A.K.Y. Haroon 1984. Diatoms of the Shatt al-Arab river, Iraq. Nova Hedwigia 39(3-4): 513-544-557.

Hendy, N.I. 1964. An introductory account of the smaller algae of British coastal water, Part V, Bacillariophyceae (Diatoms). H.M.S.O., London.

Hickel, B. 1973a. Limnological investigations in lakes of Pokhara valley, Nepal. Int. Rev. ges Hydrobiol. 58(5): 659-672.

Hickel, B. 1973b. Phytoplanktons in two ponds in Kathmandu valley, Nepal. Int. Rev. ges Hydrobiol. 58(6): 835-842.

Hirano, M. 1955. Fresh water algae. In Fauna and flora of Nepal Himalaya (Ed. H. Kihara), Fauna and Flora Research Society, Kyoto University, Kyoto, Japan. pp. 5-42.

Hirano, M. 1963. Fresh water algae from the Nepal Himalaya, collected by a member of the Japanese 


\section{S. K. Rai / Our Nature (2006)4:10-19}

Climbing Expedition. Contr. Biol. Lab., Kyoto Univ., Japan. 16: 1-23.

Hirano, M. 1969. Fresh water algae from Langtang Himal, Nepal Himalaya. Contr. Biol. Lab., Kyoto Univ., Japan. 22: 1-42.

Hirano, M. 1984. Fresh water algae from East Nepal. Study reported of Baika Junior College 32: 197-215.

Hustedt, F. 1938. Systematische und ökologische Unter suchungen über die Diatomeen flora von Java, Bali und Sumatra. Archiv f. Hydrobiol. Suppl. 15: 131177, 187-295,293-506.

Hustedt, F. 1959. Die Kieselalgen Deutschlands, Österreichs Und der Schweiz, vol. 2. Koeltz Scientific Books, USA. 845p.

Hustedt, F. 1961-1966. Die Kieselalgen Deutschlands, Österreichs und der Schweiz unter Berücksichtigung der übrigen Länder Europas sowie der angrenzenden Meeresgebiete, Part 3, Vol. VII. B. Singh and M.P. Singh, Dehradun, India. 816p.

Ishida, Y. (Ed.) 1986. Studies on distribution, adaptation and evolution of micro-organisms in Nepal Himalayas (Second report). Kyoto, Japan. pp. 3-13.

Juettner I., E.J. Cox and S.J. Ormerod 2000. New or poorly known diatoms from Himalayan streams. Diatom Research 15(2): 237-262.

Juettner I., E. Reichardt and E.J. Cox 2004. Taxonomy and ecology of some new Gomphonema species common in Himalayan streams. Diatom Research 19(2): 235-264.

Juettner, I., H. Rothfritz and S.J. Ormerod 1996. Diatoms as indicators of river quality in the Nepalese Middle hills with consideration of the effects of habitat-specific sampling. Freshwater Biology 36: 475-486.

Juettner I., S. Sharma, B.M. Dahal, S.J. Ormerod, P.J. Chimonides and E.J. Cox 2003. Diatoms as indicators of stream quality in the Kathmandu Valley and Middle Hills of Nepal and India. Freshwater Biology 48: 2065-2084.

Misra, P.K., S.K. Rai and M.N. Srivastava.(In Press). Diatom flora of Nepal. J. Bomb. Nat. Hist. Mus

Nakanishi, M. 1986. Limnological study in Phewa, Begnas and Rupa lakes. In Studies on distribution, adaptation and evolution of microorganisms in Nepal Himalayas (Second report) (Ed. Y. Ishida), Ministry of Education, Science and Culture, Kyoto, Japan. pp. 3-13.

Patrick, R. and C.W. Reimer 1966. The diatoms of the United States, exclusive of Alaska and Hawaii. Monograph of the Academy of Natural Sciences, Philadelphia, No. 13, Vol. I. 688p.

Prasad, B.N. and M.N. Srivastava 1992. Fresh water algal flora of Andaman and Nicobar Islands, Vol. I, B. Singh and M.P. Singh Publ., Dehradun, India. $369 \mathrm{p}$.

Rai, S.K. 2005. Preliminary report of diatoms from Maipokhari lake, Ilam, Nepal. Our Nature 3(1): 2630.

Rai, S.K. and R.K. Rai 2005. Some bacillariophycean algae from Biratnagar, Nepal. Ecoprint 12: 71-76.

Rothfritz, H., I. Juettner, A.M. Suren and S.J. Ormerod 1997. Epiphytic and epilithic diatom communities along environmental gradients in the Nepalese Himalaya: Implications for the assessement of biodiversity and water quality. Archiv f. Hydrobiol. 138(4): 465-482.

Simkhada, B. and I. Juettner 2006. Diatoms in ponds and small lakes of the Kathmandu Valley, Nepalrelationships with chemical and habitat characteristics. Arch. Hydrobiol. 166(1): 41-65.

Simkhada, B., I. Juettner and P.J. Chimonides 2006 Diatoms in lowland ponds of Koshi Tappu, eastern Nepal- relationships with chemical and habitat characteristics, Internat. Rev. Hydrobiol. 91(6): 574593.

Sinnu, N.A. and L.E. Squires 1985. Diatoms of the Damour river, Lebanon. Nova Hedwigia 41(1-4): 291-320-341.

Smith, G.M. 1933, 1950. The fresh water algae of the United States, McGraw-Hill Book Company Inc., New York, 2nd edn. 719p.

Suxena, M.R. and V. Venkateswarlu 1968. Algae of the Cho Oyu (E. Himalaya) Expedition-I. Bacillariophyceae. Hydrobiologia 32:1-26.

Suxena, M.R., V. Venkateswarlu, and V.S. Rao 1972. Algae of the Cho Oyo (E. Himalaya) Expedition-II. Bacillariophyceae-II. Nova Hedwigia 23(2-3): 415426.

Tiffany, L.H. and M.E. Britton 1952. The algae of Illinois. Hafner Publishing Co., New York. 407p. 